\section{OECD urges changes for 1992} Munich

SWEEPING changes in science and technology policy will be required if Switzerland is to meet the challenge of the internal European market planned for 1992. That is one conclusion of a report* released by the Paris-based Organisation for Economic Co-operation and Development (OECD) in Berne this week. The review was carried out at the request of the Swiss government.

The survey team of three international examiners based their report on a series of site visits to Swiss laboratories, universities and public and private institutions.

The recommendations urge changes in policy at federal and cantonal levels as well as in universities and in industry. The reviewers found a "distressing" lack of cohesion in national science policy, with a resulting parochialism and slowness to change. Such traits may leave Switzerland "almost isolated in Western Europe" given the country's decision to remain outside the European Community (EC).

The most striking recommendation is the creation of a "secretary of state" for science and technology in the Federal Department for Home Affairs. This official would coordinate federal and cantonal policies as well as Swiss participation in international programmes.

The OECD report encourages Switzerland to invest more in research and to do so more effectively. In spite of being the richest of all OECD member countries, the report says that "public resources for research do not match those of most other OECD countries". The high percentage of the gross domestic product invested in research comes about because of researchintensive pharmaceutical and electromechanical industries. OECD strongly recommends that the Swiss government streamline the diffuse structure for research policy-making and establish a "national research budget" - at present decisions are made at a local level in the departments.

The lack of major public research institutions (with the single exception of the Paul Scherrer Institute for nuclear research) comparable to those elsewhere in Europe gives the team the impression of "weakness, dispersal and fragmentation of public R\&D funding," said OECD.

Among the new programmes recommended by OECD are "substantial" national research programmes in information technology, new materials and biotechnology. The lesson learned when Switzerland "missed the turning" on the electronics road - and failed to develop an indigenous industry in digital watches or other electronic products - must not

* Reviews of National Science and Technology Policies: Switzerland. The report, including an account of the review meeting held in Berne on 3 March, will appear in book form later this year. be forgotten, warned OECD.

OECD concurred with some university researchers and industrialists (see Nature 336, 331; 24 November 1988) that Switzerland needs a publicity campaign explaining the benefits of science to the public and to school leavers. Distressingly few Swiss students are studying science and engineering, raising doubts about the future supply of skilled personnel.

On the Swiss National Science Foundation, which supports much of the basic research at Swiss universities, the report called "unhealthy" the practice of reducing individual project allocations by up to 30 per cent to allow more proposals to succeed. This encourages groups to submit inflated grant proposals and can prevent some projects from achieving "critical mass."

\section{RESEARCH COUNCILS MRC offers more}

\section{London}

THE British Medical Research Council (MRC) wants to increase the pay of graduate students in the hope of stemming the growing shortage of young researchers. Last week, the council asked the Department of Education and Science (DES) to allow an increase from just under $\mathfrak{£ 3 , 0 0 0}$ to $£ 3,500$ in the stipends payed to the holders of its basic research studentships from next September. In doing so, the council is planning to break with the traditional method of calculating graduate students' pay using a DES formula linking it with the maintenance grants for which undergraduates are eligible.

The council also wishes to offer an extra $£ 500$ a year to graduate students working on its directed AIDS programme of research, which would be the first time that pay differentials not based on location had been offered. The stipends paid to holders of research council studentships are usually tax-free.

The problem of attracting talented young researchers is also worrying the Advisory Board for the Research Councils. At a meeting organized by the Royal Society last week, ABRC chairman Sir David Phillips said that the shortage of research manpower would be the most serious problems the research councils would have to face in the 1990s.

ABRC's Biotechnology Advisory Group is now urging the board to set up a formal review of the manpower shortage and to suggests ways in which it might be remedied. One member of the group, Professor Peter Dunhill of University College, London, says that if nothing is done about the shortage, all the councils' initiatives in biotechnology could fall apart.

Christine McGourty
The report repeats the commonly voiced fear that, without subsidies, the small and medium-sized companies forming a large part of Swiss industry will not be able to compete with their rivals in EC countries.

Rounding out the OECD recommendations is a list of conditions to be met if Switzerland's "production apparatus" is to face the needs of modernization. The list was first prepared by the Battelle Institute in 1983 in a study of what had gone wrong with Swiss industry in the 1970s. The Battelle Institute said Swiss industry should take more risks in introducing new technology, that large and small companies should cooperate more closely, and that the banks should take a greater interest in the promotion of new technology. OECD said that the recommendations are "still valid today."

Steven Dickman

\section{NAGYMAROSDAM \\ Objectors find a voice}

\section{London}

THREE members of the Hungarian National Assembly are in danger of losing their jobs because of their electors' objections to the controversial GaboikovNagymaros hydroelectric scheme. After a majority of the assembly voted for completion of the Hungarian part of the scheme, three constituencies (two in Budapest and one in Szeged) have voted to recall the mandates of their representatives under a previously unused provision of the Hungarian constitution.

The decisions reflect growing opposition in Hungary to the Nagymaros dam, part of a joint project with Czechoslovakia. There are demands that the government should annul its treaty obligations to Czechoslovakia (as well as the construction debt to Austria), and that Hungary should pull out of the scheme unilaterally.

The decisions also reflect a new political awareness in Hungary. In a one-party system (as at present), the right of recall is a guarantee that constituents' views will be accurately represented in the assembly. (A fourth deputy is threatened with recall for reasons unconnected with the dam.) But there are signs that the ruling Socialist Workers' Party may abdicate its monopoly; the Central Committee has now accepted the principle of a multi-party system with appropriate "checks and balances".

But whether this will allow the emergence of a 'green' party in Hungary is uncertain. Janos Vargha, one of the leaders of the 'Danube circle' which has campaigned against the dam told a recent conference of environmentalists that a green party could compromise the independence of existing groups.
Vera Rich 